\title{
MENGEMBANGKAN KETERAMPILAN MENYIMAK MELALUI KEGIATAN BERCERITA DENGAN BIG BOOK PADA ANAK USIA 5-6 TAHUN
}

\author{
Tri Ayu Supartini ${ }^{1}$, Adriani Rahma Pudyaningtyas ${ }^{1}$, Nurul Kusuma Dewi ${ }^{1}$ \\ ${ }^{1}$ Program Studi PG-PAUD, Universitas Sebelas Maret Surakarta \\ E-mail: triayusupartini709@gmail.com, \\ adriani.rahmapudyaningtyas@ @staff.uns.ac.id,nurulkusuma03@gmail.com
}

\begin{abstract}
ABSTRAK:
Penelitian ini bertujuan untuk meningkatkan keterampilan menyimak pada anak usia 5-6 tahun melalui penerapan kegiatan bercerita menggunakan big book sebagai media pembelajaran. Metode penelitian ini merupakan penelitian tindakan kelas yang dalam pelaksanaanya dilakukan selama dua siklus.Setiap siklus terdiri dari dua pertemuan dengan empat tahap di setiap pertemuan yaitu perencanaan, pelaksanaan tindakan, observasi, dan refleksi.Teknik pengumpulan data dilakukan melalui observasi, wawancara, dokumentasi, dan tes.Uji validitas data menggunakan triangulasi sumber dan triangulasi teknik.Teknik analisis data kualitatif menggunakan model interaktif sedang teknik analisis data kuantitatif menggunakan model deskriptif komparatif.Hasil penelitian ini menunjukkan adanya peningkatan pada keterampilan menyimak yaitu presentase ketuntasan pada pratindakan sebesar $27.7 \%$. Siklus I diperoleh hasil sebesar $44.4 \%$, dan siklus II mencapai 77.7\%.Peningkatan tersebut ditandai dengan keberhasilan anak menjawab pertanyaan sesuai isi cerita, mengurutkan gambar sesuai alur cerita, dan menceritakan kembali cerita. Berdasarkan paparan di atas, dapat disimpulkan bahwa kegiatan bercerita menggunakan media big book dapat mengembangkan keterampilan menyimak anak usia 5-6 tahun.
\end{abstract}

Kata kunci: Keterampilan menyimak, kegiatan bercerita, big book, anak usia 5-6 tahun

\section{ABSTRACT:}

This study aimed to improve listening skills in children aged 5-6 years through the application of storytelling activities with big book as a learning media. This research was a classroom action research which this stages in implementation was carried out for two cycles. Each cycle consisted of two meetings with four satges in every meeting that were planning, action, obsevation, and reflection stage. Validity test of the data used source and technical triangulation. Analysis technique of valitatif data used interactive model while quantitative data analysis used a comparative descriptive model. The result of this study indicated an increase in listening skill, that was the percentage of pre-treatment completeness of $27.7 \%$. The first cycle results obtained at $44.4 \%$ and the second cycle reached $77.7 \%$. The improvement was marked by the success of the children by answering questions according to the content of the story, sorting the image according to the story line and retelling the story. Based on the explanation above, it can be concluded that the activities of storytelling using big book media can improve the listening skill of children aged 5-6 years.

Keywords: Listening skills, storytelling activities, big book, children aged 5-6 years 


\section{PENDAHULUAN}

Anak usia dini merupamasa anak memasuki masa peka, masa seluruh aspek perkembangan dan pertumbuhannya dengan sangat pesat. Pekerti (2014) mengungkapkan bahwa masa peka, merupakan masa pematangan fungsi fisik dan psikis sehingga siap merespon stimulus yang diberikan oleh lingkungan. Masa ini adalah waktu yang tepat sebgai fondasi awal dalam mengembangkan seluruh aspek perkembangan anak.

Salah satu aspek perkembangan yang harus dikembangkan dalam diri anak adalah aspek perkembangan bahasa.Saddhono dan Slamet (2012) menyatakan secara berturutan pemerolehan keterampilan bahasa pada umumnya dimulai dari keterampilan menyimak, berbicara, membaca dan menulis.Keterampilan menyimak merupakan suatu proses kegiatan mendengarkan lambang-lambang lisan dengan penuh perhatian, pemahaman, apresiasi, serta interpretasi untuk memperoleh informasi, menangkap isi atau pesan serta memahami makna komunikasi yang telah disampaikan sang pembicara melalui ujaran atau bahasa lisan (Tarigan, 2008).

Keterampilan menyimak pada anak usia 5-6 tahun berdasarkan Standar Tingkat Pencapaian Perkembangan Anak
(STPPA) yang termuat Permendikbud No.146 tahun 2014 terdiri dari (1) Menceritakan kembali cerita yang didengar dengan kosa kata yang lebih dan (2) Melaksanakan perintah yang lebih kompleks sesuai aturan yang disampaikan.

Gulec dan Durmus (2014) yang mengatakan bahwa pelatihan menyimak yang dimulai sejak usia dini merupakan proses pelatihan pembelajaran seseorang. Manyimak dapat menjadi salah satu cara untuk melatih anak menjadi seorang pembelajar dengan mendengarkan hal-hal yang ada disekitarnya.

Berdasaran hasil observasi dan wawancara yang di lakukan di TK MTA 01 Kebakkramat didapatkan bahwa keterampilan menyimak anak tidak berkembang secara optimal. Hal ini terlihat dari beberapa anak belum dapat memahami dan mengingat isi cerita yang disampaikan oleh guru. Observasi yang dilakukan pada tanggal 26 Juli 2018 dari 18 jumlah anak berdasarkan indikator capaian perkembangan keterampilan menyimak dalam aspek memahami isi cerita pada indikator menjawab pertanyaan terdapat 12 anak yang belum bisa menjawab pertanyaan sesuai isi cerita. Indikator mengurutkan gambar sesuai dengan alur cerita, 12 belum tuntas.Indikator menceritakan kembali cerita terdapat 12 anak hanya mampu menceritakan kembali cerita yang 
didengarnya pada bagian awal cerita atau dapat dikatakan belum tuntas.

Upaya yang dapat dilakukan untuk menggembangkan keterampilan menyimak pada anak, salah satunya yaitu dengan kegiatan bercerita dengan media big book. Otto (2015) menyatakan ketika guru melakukan kegiatan pemberian cerita guru menyediakan kesempatan bagi anak untuk belajar lebih mengenai bahasa, komunikasi makna, dan beragam tujuan membaca. Anak akan belajar banyak hal dari cerita/kisah yang disampikan oleh guru.Kegiatan bercerita akan lebih mudah bagi guru dan lebih menarik bagi anak apabila guru menggunakan alat peraga/ media, salah satu mediayang dapat digunakan oleh guru adalah big book.

$$
\text { Karges mendefinisikan big }
$$

book adalah buku bergambar yang diperbesar dengan memiliki "kualitas khusus" (Solehuddin, 2007). Ukuran gambar yang cukup besar dapat membantu anak dalam memahami isi cerita. Masitoh (2014) berpendapat bahwa penggunaan ilustrasi gambar baiknya cukup besar, berwarna, serta menggambarkan jalan cerita yang disampiakan sehingga dapat dilihat dengan mudah oleh anak. Media big book dapat membantu anak memahami informasi yang diberikan melalui gambar-gambar dan kata-kata yang terdapat dalam media tersebut. Big book memberikan anak pengalaman baru dalam mendapatkan sebuah cerita yang membantu anak dalam mengembangkan bahasa lisan melalui kegiatan menyimak terhadap cerita yang diberikan oleh guru. Rumusan masalah dalam penelitian ini apakah penerapan kegiatan bercerita dengan media big book dapat mengembangkan keterampilan menyimak anak usia 5-6 tahun TK MTA 01 Kebakkramat, Karanganyar.

Penelitian ini bertujuan untuk mengembangkan keterampilan menyimak anak usia 5-6 tahun dengan menerapkan kegiatan bercerita menggunakan media big book.

\section{Katerampilan Menyimak Anak}

Menyimak merupakan keterampilan bahasa yang pertama dilalui oleh setiap manusia dan saling berkaitan dengan keterampilan bahasa yang lain, Ranukadevi (2014) yang mengatakan bahwa menyimak sebagai keterampilan bahasa yang sangat mendasar secara konsisten saling terkait campur tangan dengan kemampuan bahasa lainnya, yaitu berbicara, membaca, dan menulis. Keterampilan menyimak dengan keterampilan bahasa yang lain saling terkait dan saling mempengaruhi. Seorang anak memperoleh bahasa dan dapat berbicara dengan cara menyimak perkataan orang lain. Menyimak merupakan aktivitas dasar manusia yang membuatnya memiliki banyak 
pengetahuan (Musfiroh, 2008). Seberapa baik anak menyimak memiliki dampak yang besar terhadap efektifitas kerjanya, dan terhadap kualitas hubungannya dengan orang lain (Hermawan, 2012). Tyagi (2013) menjelaskan keterampilan menyimak terdiri dari mendengar; memahami; mengingat; mengevalusai dan merespon.

\section{Kegiatan Bercerita}

Dhieni, dkk (2007) dan Madyawati (2016) mengungkapkan bercerita adalah suatu kegiatan yang dilakukan seseorang kepada orang lain secara lisan dengan alat mengenai apa yang harus disampaikan dalam bentuk pesan, informasi, atau hanya sebuah dongeng yang dikemas dalam bentuk cerita yang dapat didengarkan dengan rasa menyenangkan. Kegiatan bercerita adalah suatu kegiatan yang dilakukan seseorang kepada orang lain dengan alat atau tanpa alat tentang suatu hal yang harus disampikan dalam bentuk pesan, informasi, atau hanya sebuah dongeng yang untuk didengarkan dengan rasa yang menyenangkan karena disampaikan dengan menarik.

Melalui kegiatan bercerita guru dapat menanamkam pesan moral yang terkandung dalam cerita yang disampaikan serta memberikan wawasan pengetahuan bagi anak ketika anak mendengar cerita yang baru dan melatih keterampilan menyimak yang dimilikinya serta meningkatkan kemampuan kognitif yaitu anak dapat mengembangkan kemampuan berpikir kritis dan menanggapi peristiwa yang terjadi dalam cerita, kemampuan afektif yaitu setiap pesan yang termuat dalam cerita dapat diaplikasikan dalam kehidupan sehari-hari anak serta keterampilan psikomotor yaitu anak dapat menirukan hal-hal yang ada dalam cerita yang disampaikan oleh guru.

\section{Big Book}

Sulaiman, (2017) menyatakan big book adalah buku bacaan yang memiliki ukuran, tulisan, dan gambar yang diperbesar. Hal ini sama dengan pendapat Lynch (2008) yang menyatakan big book memiliki cetakan yang besar dengan ilustrasi gambar yang berwarna.Ukuran, tulisan dan gambar yang besar dan berwarna akan sangat membantu dalam pembelajaran dikelas karena big book dengan cetakan yang besar dan gambar yang berwarna-warni dapat mencakup seluruh anak dalam satu kelas untuk berbagi cerita, puisi dan fakta-fakta yang bagus dan menarik. Berdasarkan uraian tersebut dapat disimpulkan bahwa media big book merupakan media pembelajaran dalam bentuk buku yang penuh dengan gambar berwarna, yang digunakan oleh guru dengan berbagi bacaan yang secara umum diperuntukkan bagi anak di dalam kelas. Dengan adannya media big book 
anak akan merasa tertarik dan senang dalam mengikuti kegiatan pembelajaran dikelas (Astari, Pudjawan \& Antara, 2016).

\section{METODE}

Penelitian ini dilakukan di TK MTA 01

Kebakkramat,

Karanganyar.Waktu penelitian dilaksaakan selama 6 bulan pada bulan Juli sampai Desember 2018. Penelitian ini menggunakan jenis pendekatan kuantitatif dan kualitatif dengan jenis penelitian tindakan kelas model Kurt Lewin. Penelitian dilakukan sebanyak dua siklus penelitian dengan dua pertemuan di setiap pertemuan terdapat empat tahap penelitian yaitu tahap perencanaan, tahap pelaksanaan tindakan, tahap observasi dan tahap refleksi.Subyek penelitian ini adalah anak di kelompok B1 TK MTA 01 Kebakkramat, Karanganyar dengan jumlah anak sebanyak18 anak terdiri dari 7 anak laiki-laki dan 11 anak perempuan.

Tabel.1 Indikator Penilaian Keterampilan Menyimak Anak Usia 5-6 Tahun

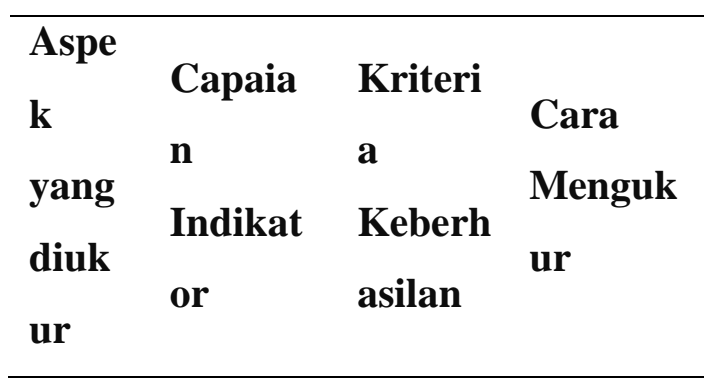

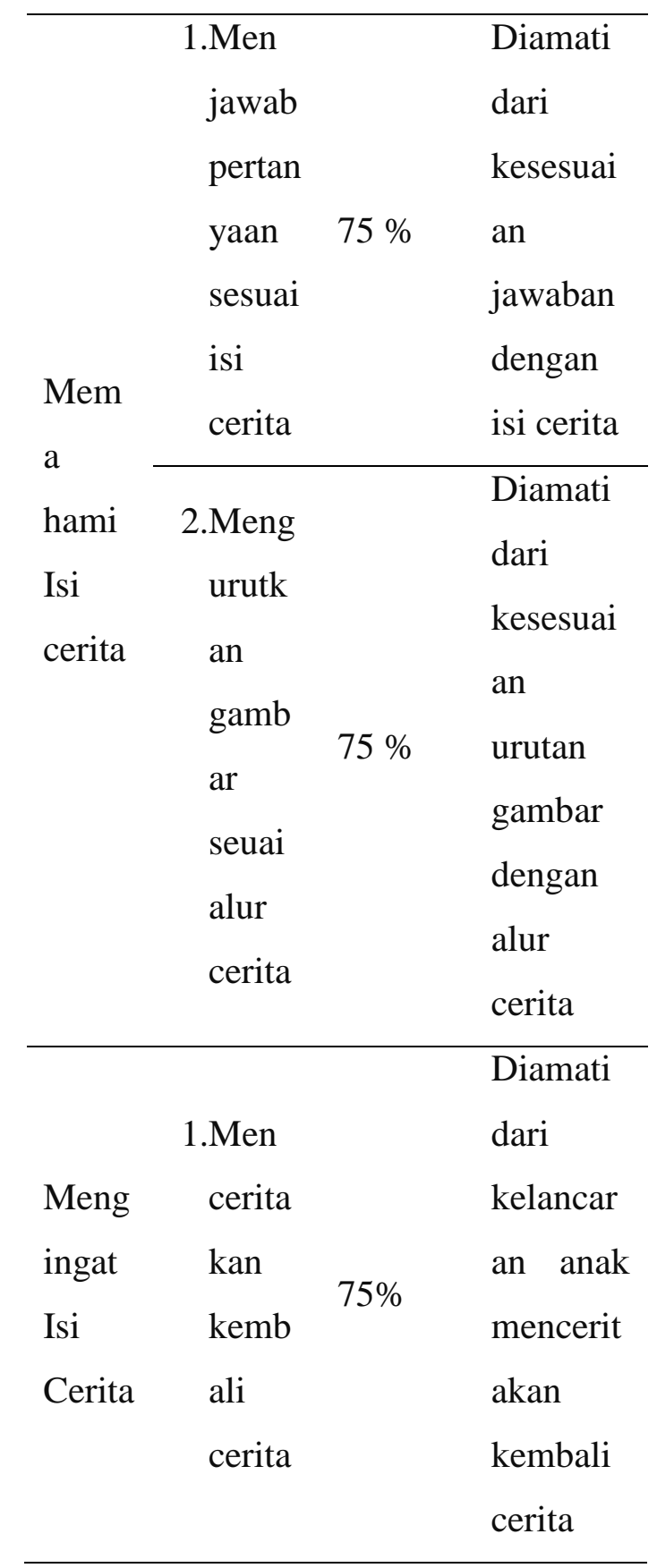

Tabel 1 menunjukkan jenis data yang digunakan dalam penelitian yaitu data kulaitatif dan data kuantitatif yang berisikan informasi tentang keterampilan menyimak anakyang terdiri dari menjawab pertanyaan sesuai isi cerita, mengurutkan gambar sesuai alur cerita dan menceritakan kembali cerita baik dari LKA anak, vidoe 
pembelajaran maupun foto dokumentasi. Sumber data yang digunakan adalah sumber data primer berupa aktivitas anak kelompok B1 dan wawancara dengan guru kelas, sedangkan sumber data sekunder berupa RPPH, skenario pembelajaran dan dokumentasi selama proses pembelajaran. Teknik pengumpulan data yang dilakukan terdiri dari observasi, wawancara, dokumentasi, dan tes unjuk kerja.Uji validitas data kualitatif menggunakan triangulasi sumber dan triangulasi teknik, sedangkan data kuatitatif menggunakan tringulasi konstruk.Teknik analisis data kuantitatif dalam penelitian ini menggunakan data komparatif yaitu membandingkan hasil persentase pratindakan dan siklus yang telah dilakukan, sedangkan data kualitatif terdiri dari empat tahap yaitu pengumpulan data, reduksi data, dan penyajian data.

\section{HASIL}

Berdasarkan Observasi dan analisis data didapatkan bahwa sebelum diberikan tindakan diperolah data sebesar $27.7 \%$ atau sebanyak 5 anak tuntas kemudian pada siklus I diperoleh hasil sebesar $44.4 \%$ atau sebanyak 8 anak dan pada siklus II mengalami peningkatan dengan diperoleh hasil sebesar $77.7 \%$ atau sebanyak 14 anak tuntas.

Hasil ketuntasan keterampilan menyimak anak usia 5-6 tahun di TK
MTA 01 Kebakkramat tahun ajaran 2018/2019 dapat dilihat pada tabel di bawah ini:

Tabel 2. Hasil Nilai Keterampilan menyimak anak Pratindakan, Siklus I, dan Siklus II

\begin{tabular}{|c|c|c|c|c|c|c|}
\hline \multirow{3}{*}{ Ket } & \multirow{2}{*}{\multicolumn{2}{|c|}{$\begin{array}{l}\text { Pra } \\
\text { tindakan }\end{array}$}} & \multirow{2}{*}{\multicolumn{2}{|c|}{$\begin{array}{l}\text { Siklus } \\
\text { I }\end{array}$}} & \multirow{2}{*}{\multicolumn{2}{|c|}{$\begin{array}{l}\text { Siklus } \\
\text { II }\end{array}$}} \\
\hline & & & & & & \\
\hline & $\mathrm{f}$ & $\%$ & $\mathrm{f}$ & $\%$ & $\mathrm{f}$ & $\%$ \\
\hline Tunt & & 27,7 & & 44,4 & & 77.7 \\
\hline as & $J$ & 8 & 0 & 4 & 14 & 8 \\
\hline \multicolumn{7}{|l|}{ Belu } \\
\hline $\mathrm{m}$ & 1 & 72,2 & 1 & 55,5 & \multirow{2}{*}{4} & 22.2 \\
\hline Tunt & 3 & 2 & 0 & 6 & & 2 \\
\hline as & & & & & & \\
\hline
\end{tabular}

keterampilan menyimak pada anak usia 56 tahun di TK MTA 01 Kebakkramat dapat disajikan dalam bentuk gambar 1 berikut ini:

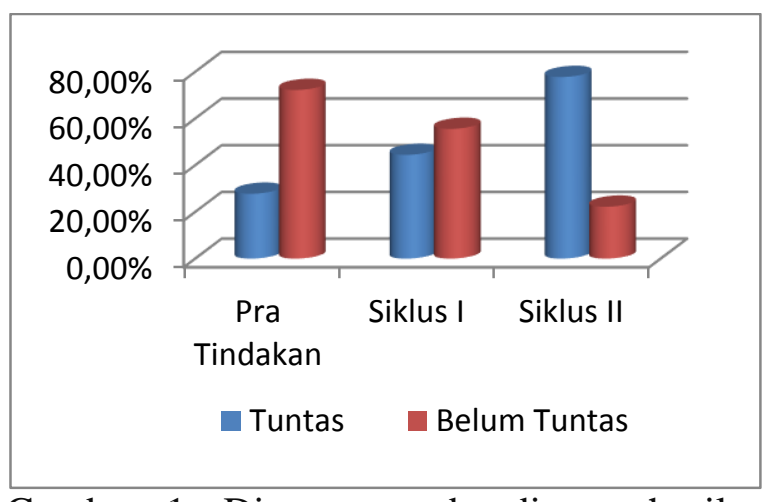

Gambar 1. Diagram perbandingan hasil Tindakan

- Gambar 1 menunjukkan perbandingan hasil yang diperoleh pada setiap pemberian tindakan.Peningkatan yang diperoleh 
ditandai dengan meningkatnya nilai setiap indikator di setiap siklus.Indikator menjawab pertanyaan pada siklus I sebesar $66.12 \%$ meningkat pada siklus II menjadi 88.8\%.Indikator mengurutkan gambar sesuai alur cerita siklus I menperoleh hasil $55.56 \%$ pada siklus II $77.78 \%$.indikator menceritakan kembali cerita siklus I diperoleh 55.56\% siklus II 55.56\%. Hasil yang diperoleh pada setiap indikator diatas menunjukkan bahwa kegitan bercerita dengan big book dapat menstimulus keterampilan menyimak anak.Moeslichatoen (Masitoh dkk, 2014) yang mengungkapkan bahwa salah satu manfaat bercerita yaitu memberikan pengalaman berlatih mendengarkan bagi anak. Keterampilan menyimak anak akan menjadilebih baik jika guru bercerita menggunak media. Rusmiyati (2014) menyatakan bahwa mediabig book dapat meningkatkan kecerdasan linguistik anak melalui kegiatan bercerita yang dilakukan oleh guru.

\section{PEMBAHASAN}

Tujuan dari penelitian ini untuk mengembangkan keterampilan menyimak anak usia 5-6 tahun TK MTA 01 Kebakkramat Tahun Aajaran 2018/2019 melelui metode bercerita menggunakan media big book telah dilaksanakan sebanyak dua siklus, setiap siklus terdiri dari dua pertemuan. Indikator penelitian yang digunakan yaitu menjawab pertanyaan sesuai isi cerita, mengurutkan gambar sesuai dengan alur cerita dan menceritakan kembali cerita.

Langkah - langkah bercerita dengan media big book yang digunakan dalam penelitian ini diantaranya: 1) Menetapkan tujuan dan tema pembelajaran. Tujuan dan tema dalam penelitian ini disesuaikan dengan kurikulum yang digunakan di TK MTA 01 Kebakkramat; 2) Menetapkan bentuk kegiatan cerita dan alat peraga yang digunakan. Bentuk kegiatan cerita yang digunakan adalah bercerita menggunakan alat peraga berupa media big book dengan jumlah sebanyak empat buah; 3) Mengatur tempat duduk anak. Tempat duduk anak di atur menjadi setengah lingkaran dengan posisi guru berada di tengah sehingga anak dapat menyimak guru ketika menyajikan cerita dan media yang diguna guru juga dapat dilihat anak dari segala arah; 4) Menunjukkan big book pada anak dan mengkomunikasikan judul dan tema cerita. Memperlihatkan sampul depan dan belakang, gambar pada setiap halaman dan mengungkapkan judul pada anak. Cerita yang digunakan dalam penelitian ini sebanyak empat judul cerita dengan tema yang disesuaikan dengan tema di TK MTA 01 Kebakkramat, pada setiap pertemuan guru akan berceritakan cerita yang berbeda-beda agar anak tidak bosan dan 
memiliki pengetahuan yang lebih; 5) Kegitan bercerita dimulai. Kegiatan bercerita dimulai dengan guru menggali pengalaman anak

Pelaksanaan penelitian ini dalam pengunaan big book akan menggunakan pendapat dikemukakan oleh Lynch (2008), tetapi penulis hanya akan menggunakan sesi pertama. Hal ini dikarenakan pada sesi ke dua sampai sesi lima cara penggunaan big book lebih ditujuan untuk melatih anak dalam membaca permulaan, sedang dalam penelitian ini mengembangkan keterampilan menyimak pada anak. pelaksanaan sesi pertama dilakukan sesuai dengan lankah yang dikemukakan oleh Lynch (2008) yang terdiri dari 1) Atur posisi duduk anak; 2) Memperlihatkan big book pada anak mulai dari sampul depan dan belakang, gambar pada setiap halaman dan minta anak untuk berkomentar dan memprediksi cerita; 3) Membandingkan prediksi anak dengan cerita; 4) Tanyakan jalan ceritanya pada anak.

Hasil penelitian ini dapat diketahui bahwa kegiatan bercerita dengan media big book dapat meningkatkan keterampilan menyimak anak usia 5-6 tahun TK MTA 01 Kebakkramat tahun ajaran 2018/2019. Hal ini dibuktikan dengan tercapainya seluruh indikator keberhasilan pada setiap aspek penilaian. Keterampilan menyimak anak pada kelas B1 TK MTA 01 Kebakkramat yang awalnya rendah yang ditunjukkan dengan masih banyak anak yang tidak mengingat dan memahami sebuah cerita setelah diberikan tindakan kegiatan bercerita dengan media big book keterampilan menyimak anak dapat meningkat seusuai dengan yang diharapkan yaitu tercapainya semua indikator kinerja yang digunakan.

Keterampilan menyimak pada dalam diri seorang anak sangat penting untuk terus dikembangkangkan, hal ini dikarenakan menyimak merupakan aktivitas dasar manusia yang membuatnya memiliki banyak pengetahuan (Musfiroh,2008). Manusia begitu juga anak akan membutuhkan banyak pengetahuan untuk menjalani kehidupannya, untuk itu penting bagi anak dalam mengembangkan keterampilan menyimak untuk mendapatkan pengetahuan, selain itu menyimak juga dibutuhkan dalam menjalin hubungan dengan orang lain. Seberapa baik seorag anak dalam menyimak memiliki dampak yang besar terhadap efektifitas kerja, dan kualitas hubungannya dengan orang lain (Hermawan, 2012). Menyimak dengan baik akan mempermudah bagi anak untuk menjalin hubungan dengan orang lain.

$$
\text { Tyagi (2013) menjabarkan }
$$
keterampilan menyimak terdiri dari lima aspek yaitu mendengar, memahami, mengingat, mengevaluasi dan merespon. Penelitian ini menggunakan dua aspek 
menyimak yang dikemukakan oleh Tyagi yaitu memahi dan mengingat yang kemudian dikembangkan menjadi tiga indikator penilaian yaitu menjawab pertanyaan sesuai isi cerita, mengurutkan gambar sesuai alur cerita dan menceritakan kembali cerita yang mengacu pada Pemendikbud N0.146.tahun 2014. Hasil penelitian yang telah dilaksanakan diperoleh hasil sebesar $77.7 \%$ atau sebanyak 14 anak tuntas dan $22.2 \%$ atau sebanyak 4 anak belum tuntas. Hasil pengamatan menunjukkan anak yang belum tuntas dikarenakan ada 1 anak yang pasif selama pembelajaran maupun dalam kegiatan yang lain dari siklus I sampai Siklus II, 1 anak hiperaktif sehingga tidak mau duduk diam untuk menyimak cerita dan selalu menganggu temam, 1 anak yang kadang mau mengerjakan dan kadang tidak mau mengerjakan dan anak terlihat antusias selama pembelajaran namun belum tuntas karena berdasarkan wawancara kepada guru dan hasil observasi memang kemampuan anak lebih rendah dibandingkan yang lain.

Penelitian ini selain menunjukkan bahwa pemberian kegiatan bercerita menggunakan media big book dapat menstimulasi perkembangan menyimak pada anak. Media big bookmemiliki pengaruh dalam memenuhi indikator kinerja penilaian. Indikator menjawab pertanyaan sesuai isi cerita dapat dilakukan dengan mudah karena anak yang tertarik dengan media yang digunakan akan menyimak cerita yang diberikan oleh guru dari awal sampai akhir, jadi anak dapat mengetahui apa saja yang terjadi dalam cerita yang dibawakan oleh guru dan dapat menjawab pertanyaan yang diberikan oleh guru.

Indikator mengurutkan gambar sesuai alur cerita, dengan menggunakan media big bookakan mudah mengerjaknnya karena gambar yang ditunjukkan besar dan mewakili cerita, jadi anak yang menyimak cerita dengan baik dari awal samapi akhir cerita dapat dengan mudah mengerjakan LKA mengurutkan gambar sesuai alur cerita. Kemudian, pada indikator menceritakan kembali cerita, anak sangat antusias dalam bercerita menggunakan big book.Anak bercerita seperti yang dilakukan oleh guru dengan menujuk gambar yang ada pada big book.

Hasil dari penelitian ini juga selain dapat mengembangkan keterampilan menyimak pada anak juga didapatkan temuan lain yaitu dapat membantu anak dalam mengembangkan keterampilan bahasa yang lain. Memperhatikan buku besar ketika cerita dibacakan membantu anak dalam meninggikan kesadaran anak akan konvensi literasi, meninggikan koordinasi mata, membangun kosakata, menguatkan konsep membaca untuk makna (Kostelnik, Soderman, Whiren, 
2017). Big book dapat membantu dalam mengembangkan keterampilan membaca dan meulis di kelas awal, menambah kosakata anak dan memperkenalkan membaca pada anak sedini mungkin. Penenlitian ini juga dapat mengembangkan beberapa bidang perkembangan, seperti perkembangan sosial emosional. Solehuddin, dkk (2008) mengungkapkan belajar dengan big book memeberikan pengalaman sosial pada anak, pada indikator menjawab pertanyaan sesuai isi cerita dan menceritakan kembali cerita yaitu rasa percaya diri anak. Anak berani maju kedepan kelas untuk tampil didepan anak lain walaupun jawaban yang diberikan kurang tepat ketika menjawab pertanyaan, anak juga berani maju kedepan kelas dengan senantiasa menawarkan diri untuk menceritakan kembali cerita walau anak belum paham benar akan cerita yang diberikan oleh guru. Anak juga dapat mengembangkan perasaan mereka sesuai dengan perasaan tokoh

Penelitian ini juga dapat mengembangkan bidang perkembangan kognitif pada diri anak. Pengunaan media big book di dalam kelas melatih siswa untuk mengaktifkan pengetahuan sebelumnya, menjadi model proses berpikir, pengamatan kata, kegiatan berbahasa, dan melatih keterampilan prediksi siswa. Media big book dapat mengembangkan kemampuan kognitif yang dimiliki anak. Anak mengingat gambar sesuai dengan alur cerita dan anak mulai belajar untuk mengalisis sederhana dan memprediksi melalui gambar yang ditunjukkan pada big book. Data-data yang diperoleh dari penelitian ini menunjukkan sebuah kesimpulan dan sekaligus menjawab hipotesis penelitian bahwa penerapan kegiatan bercerita dengan media big book dapat mengembangkan keterampilan menyimak anak usia5-6 tahun di TK MTA 01 Kebakkramat tahun ajaran 2018/2019.

\section{SIMPULAN}

Hasil penelitian yang diperoleh selama dilaksanakan tindakan dengan menerapkan metode bercerita menggunakan media big book yaitu adanya peningkatan disetiap indikator dengan hasil sebesar $88.8 \%$ untuk indikator menjawab pertanyaan sesuai isi cerita, $77.7 \%$ pada indikator mengurutkan gambar sesuai alur cerita dan $77.7 \%$ untuk indikator menceritakan kembali cerita. Media yang digunakan dengan cerita yang berbeda-beda memberikan pengalaman yang menarik dan dinanti bagi anak, sehingga anak mapu mengembangkan keterampilan menyimak berdasarkan hasil penelitian tindakan kelas yang telah dilakukan dengan metode bercerita menggunaan media big book dapat menstimulasi keterampilan 
menyimak anak usia 5-6 tahun TK MTA 01 Kebakkramat tahun ajaran 2018/2019.

DAFTAR PUSTAKA

Astari, N.L.PM., Pudjawan,K., \& Atar, P.A (2016) PemanfaatannMedia BignBook untuk KemampuannBerbahasa Anak Kelompok B2 dalamnKegiatan Ekstrakulikuler. e-jurnal Pendidikan Anak Usia Dini. Vol. 4.No.

2.https://ejournal.undiksha,ac,id/in dex.php/JJPAUD/article/viewFile/ 7756/5294. Di peroleh pada 28 Aplir 2018

DepartemennPendidikan dan Kebudayaan.n(2014). Peraturan Menteri Pendidikann dan Kebudayaann Republik Indonesia Nomor 146 tahun 2014. Jakarta : Departemen Pendidikan dan Kebudayaan.

Dhieni, dkk. (2007) .MetodenPengembangannnnBaha sa.Jakarta : Universitas Terbuka

Gulec, S., \& Durmus, N. (2015) A studynaiming to develop listening skills of elementary second grade studen. Procedia - social and behavior sciences, 191, 103-109. https://www.sciencedirect.com/sci
ence/article/pii/S18770428150274

70. Diperoleh pada 11 Maret 2018 Hermawan, H. (2012). Menyimak keterampilannBerkomunikai yang Terbaik. Yogyakarta: Graha Ilmu

Kostelnik, M.J, Soderman, A.K, Whiren, A.P. (2017).

KurikulumnPendidikan Anak UsianDininBerbasis

Perkembangan Anak (Developmentally Apropriate Practices). Depok: Kencana

Lynch, P. (2008). A Guide TonUsing Bing Books in ThenClass Room. Artikel. Scholastic Canada, Ltd : Kanada.

http://www.scholastic.ca/munsch/ downloads/AGuidetoUsingBigBo oksintheClassroom.pdf.

Diperoleh pada 28 April 2018

Madyawati, L. (2016). Strategi Pengembangan Bahasa Pada Anak Usia Dini. Jakarta: Prenadamedia Group

Masitoh, dkk. (2014). Strategi PembelajarannTK. Tangerang Selatan: Universitas Terbuka

Musfiroh, T. (2008). Memilih, MenyusunndannMenyajikan Cerita 
Untuk Anak Usia Dini.

Yogyakarta: Tiara Wacana

Otto. B. (2015) Perkembangan BahasanAnaknUsianDini. Terj. Tim Penerjemah Prenadamedia Group. Jakarta. Prenadamedia Group

Pekerti, W. 2014.Metode PengembangannSeni. Tangerang Selatan: Universitas Terbuka

Ranukadevi, D. (2014). The Role of Listening in Language Acquisition; theChallenges \&Strategies in Teaching Listening.International Journal of Education and InformationStudies, 4(1). 59 63.https://www.ripublication.com/ ijeisv1n1/ijeisv4n1_13.pdf

Diperoleh pada 8 Maret 2018.

Rusmiyati, A. (2014). Pengaruh BerceritaDengan Media Big Book TerhadapKecerdasan

LinguistikAnak TK A PAUD Saymara Kartasura Tahun Ajaran 2013/2014. Skripsi.Uniersitas MuhammadiyahSurakarta.http://e prints.ums.ac.id/28898/14/PUBLI KASI.pdf. Diperoleh pada 11 Maret 2018
Saddono, K. \& Slamet, ST. Y. (2012).Meningkatkan

KeterampilanBerbahasa

Indonesia (Teori dan Aplikasi)Bandung : Karya Putra Darwati

Solehuddin .(2007). Bermain Sebagai Sarana PerkembanganDanBelajar Anak. Jakarta : Universitas Terbuka

Solehuddin, M. dkk. (2008). PembaharuanPendidikan TK.

Jakarta: UT

Sulaiman, U. (2017). Pengaruh Penggunaan Media BigBook DalamPembelajaran Terhadap Keterampilan Literasi Siswa KelasAwal Madrasah Ibtidaiyah Negeri Banta-Bantaeng Makassar. Jurnal al-Kalam Vol. IX No. 2. Hal 193-204. http://journal.uinalauddin.ac.id/index.php/klm/articl e/view/4486 Diperoleh pada 16 Maret 2018.

Tarigan, G.H. (2008). Menyimak SebagaiSuatuKeterampilan Berbahasa. Bandung: Angkasa

Tyagi. B. (2013) Listening : An Important Skill and Its Various Aspects. An International Journal in English, 
(12), 1-8. http://www.thecriterion.com/V4/n1/Babita.pdf.

Diperoleh pada 11 Maret 2018 